
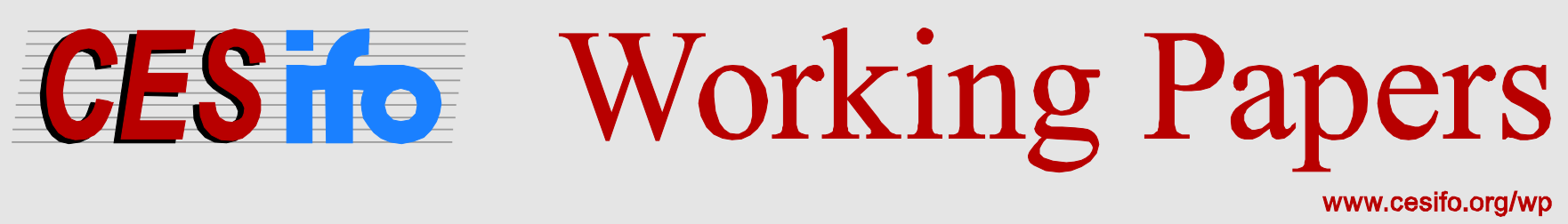

\title{
The Effects of Permanent Income Tax Cuts on Emigration from Israel
}

\author{
Tomer Blumkin \\ Yoram Margalioth \\ Michel Strawczynski
}

\section{CESIFO WORKING PAPER No. 6095 \\ CATEgory 1: Public FinANCE \\ SEPTEMBER 2016}

\footnotetext{
An electronic version of the paper may be downloaded

- from the SSRN website:

- from the RePEc website:

- from the CESifo website: WWw.SSRN.com

www.RePEc.org

www.CESifo-group.org/wp
} 


\title{
The Effects of Permanent Income Tax Cuts on Emigration from Israel
}

\begin{abstract}
In this paper we introduce an analytical framework for analyzing the effect of permanent income tax reductions on emigration and conduct an empirical analysis of their impact, based on the Israeli tax reductions during 2004-2010. We find that permanent tax reductions reduce the emigration flows from Israel. According to our findings, this effect is stronger for workers in the low-tech sector than for their high-tech counterparts, as the former appear to be more sensitive to changes in net wages. Moreover, the effect is stronger for younger workers who benefit from permanent tax reductions for a longer period during their careers, relative to older workers.
\end{abstract}

JEL-Codes: H200, J380, J610.

Keywords: permanent tax cut, emigration.

\author{
Tomer Blumkin \\ Department of Economics \\ Ben Gurion University of the Negev \\ Israel - 84105 Beer-Sheva \\ tomerblu@bgu.ac.il
}

\author{
Yoram Margalioth \\ Faculty of Law \\ Tel Aviv University \\ Tel Aviv / Israel \\ margalio@post.tau.ac.il
}

\author{
Michel Strawczynski \\ Department of Economics \& School of \\ Public Policy / Hebrew University of \\ Jerusalem / Israel \\ michel.strawczynski@mail.huji.ac.il
}

\section{September 2016}

We are grateful to Oren Tirosh for his superb research assistance, and to Adi Finkelstein for preparing the data set during the first stage of the research; thanks are also due to Yotam ShemTov for helpful remarks. We are grateful to Sapir Center at Tel Aviv University for its generous financial support. We received helpful remarks from participants in seminars at: The Federman School of Public Policy of the Hebrew University of Jerusalem, The Israeli Economic Association and The Bank of Israel. 


\section{Introduction}

A well-established theoretical and empirical finding in Public Economics is that high-income earners strongly respond to income taxation (Gruber and Saez, 2002). The literature stresses migration as one of the key channels of response (Slemrod, Saez and Giertz, 2012). Two recent influential empirical studies by Kleven, Landais and Saez (2013) and Kleven, Landais, Saez and Schultz (2014) found indeed that migration decisions were significantly affected by tax incentives, attesting to the importance of the migration margin for the design of the optimal tax-and-transfer system.

In light of growing earnings inequality, suggestions to increase the top marginal tax rates are widely discussed by policymakers and in academic circles as an effective means to promote redistributive goals. The effectiveness of such reforms depends to a large extent on the migration opportunities (overseas job prospects) available to high-income earners, which are likely to vary within the pool of top earners.

In the period 2004-2010, the Israeli Government implemented a substantial and consistent gradual pre-announced reduction of the statutory marginal income tax rates, resulting in a permanent reduction of marginal tax rates (Figure 1)..$^{2}$ The Israeli experience provides a unique opportunity to examine the impact of a permanent tax reduction on migration.

\footnotetext{
${ }^{2}$ Note that in the early 2000s the marginal tax rates for the $6^{\text {th }}$ and $7^{\text {th }}$ brackets were lower than the marginal tax rate applied to the $4^{\text {th }}$ and $5^{\text {th }}$ bracket. This apparent inconsistency was due to a threshold on National Insurance contributions at the relevant income ranges; above which the marginal contribution was zero.
} 
Figure 1

Changes in Marginal Tax Rates (income tax + national insurance contribution) 2000-2010

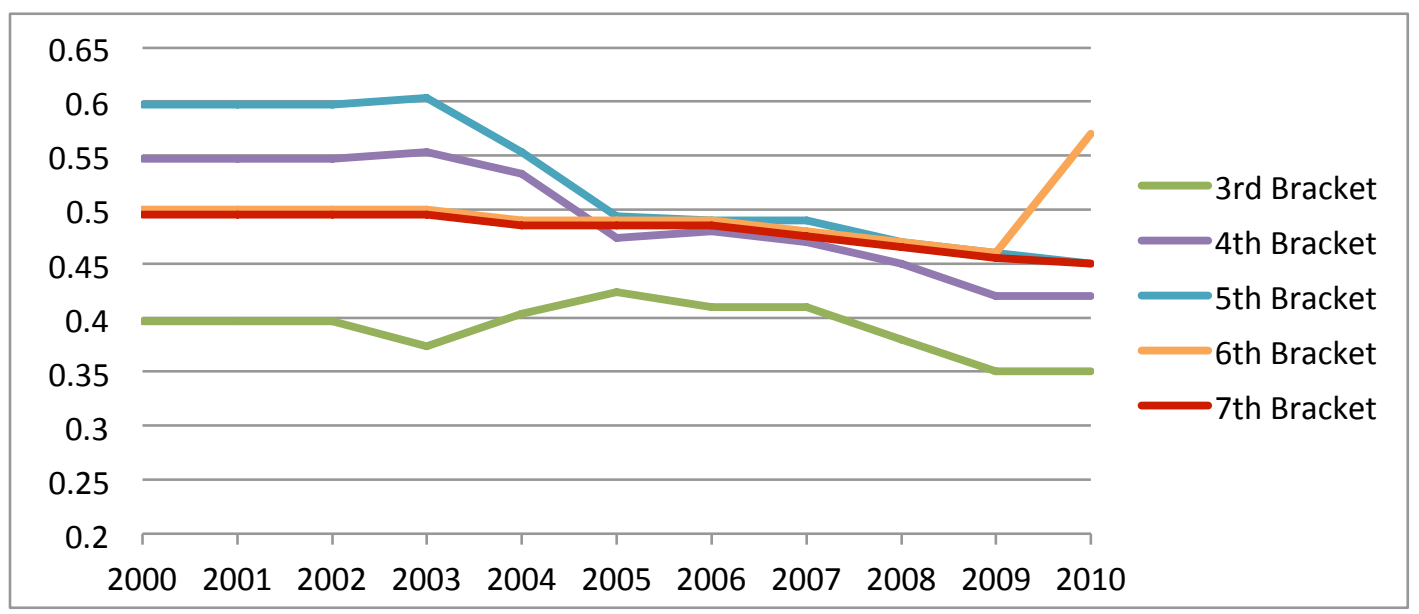

The reduction was not across the board. It affected the different income tax brackets at different intensities, resulting in a differential impact on the average tax rates, which are the relevant rates for migration decisions (Figure 2).

Figure 2

Changes in Average Tax Rates (income tax + national insurance contribution) 2000-2010

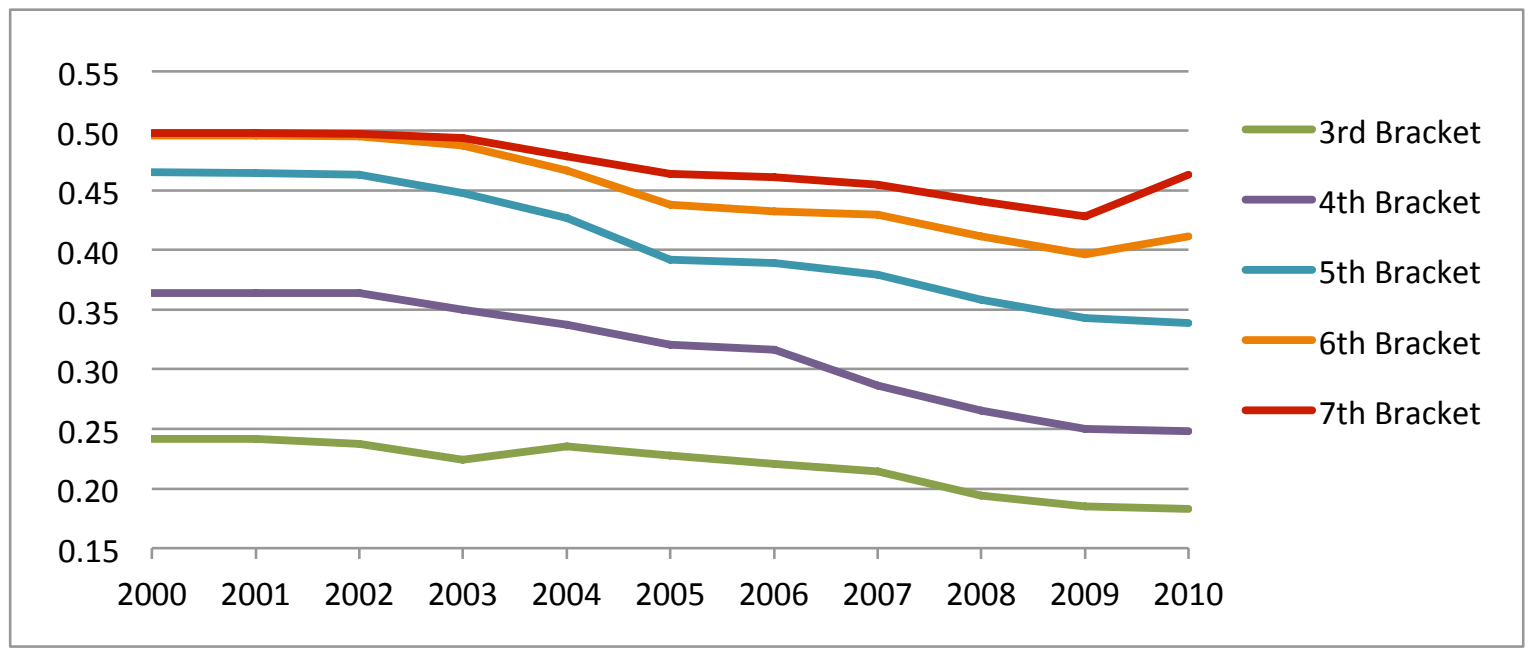

In this study, we attempt to exploit this variation in the effect on average tax rates across income levels in order to estimate the impact of these tax cuts on emigration flows of Israelis during the period 2000-2010. 


\section{A Brief Review of the Literature}

Our study relates to several strands of the existing empirical literature on the behavioral effects of taxation and on migration. There is substantial empirical evidence on the impact of tax rates and transfers on labor supply and labor income of individuals and households [for two broad surveys see Blundell and MaCurdy (1999) and Giertz, Saez and Slemrod (2012)]. An additional strand of the literature examines the impact of taxation on capital flows [Gordon and Hines (2002), Grifith and Devereux (2002) and Griffith, Hines, and Sørensen (2010)]. A third relevant strand of empirical literature deals with the wage gaps among immigrants [see, e.g., Borjas (1999)]. In a recent related paper Borjas, Kauppinen and Poutvaara (2015) showed that for the Danish population the income distribution of emigrants stochastically dominates that of non-emigrants and that self-selection was driven primarily by unobservable characteristics.

The literature examining the impact of tax incentives on international migration is relatively scarce. There are some studies that examine the migration within a federation, such as, Wrobel and Feldstein (1998), Bakija and Slemrod (2004) and Varner and Young (2011) focusing on migration within the US; and Pommerehne and Kirchgassner (1996) and Liebig et al. (2007), examining migration across Swiss Cantons. More recently, several studies examine the impact of tax incentives on international migration [Landais, Kleven and Saez (2013), Landais, Kleven, Saez and Schultz (2014) and Akcigit, Baslandze and Stantcheva (2015)]. The first paper studies the impact of tax incentives on migration of soccer players in 14 European countries in the period 1985-2008, finding an average (migration) elasticity that is close to unitary for foreign players and even a higher elasticity for top soccer players. Landais, Kleven, Saez and Schultz (2014) employ a differences-in-differences methodology to study the impact on migration of a tax reform that took place in Denmark in the beginning of the nineties, in which high-income earners (defined as individuals with an annual income 
level exceeding 103 thousands Euros, in 2009 prices) received a substantial (34 percent) tax reduction over a period of three years. The study finds a strong reaction to tax rates, with elasticity exceeding unity. Finally, Akcigit, Baslandze and Stantcheva (2015) find evidence that location decisions taken by top $1 \%$ inventors are significantly influenced by tax considerations.

The policy implications of the above documented high migration elasticities were examined in two recent theoretical studies. Lehmann, Simula and Trannoy (2014) demonstrated that migration incentives could call for setting negative marginal tax rates at the top. Blumkin, Sadka and Shem-tov (2015) have demonstrated that in the presence of labor migration and tax competition, asymptotic optimal marginal tax rates should approach zero under plausible parametric assumptions regarding the underlying migration elasticities. Both studies indicate that migration may have a considerable impact on the optimal marginal tax rates, in sharp contrast to previous studies focusing on traditional margins of response (such as participation and labor supply).

\section{Descriptive Statistics}

Before turning to our analysis, we present some descriptive statistics of our data. Table 1 shows the characteristics of migrants by year and by gender. The data are based on flows of individuals that migrate (in or out) for a period that is longer than one year. ${ }^{3}$ We show statistics for both immigrants and emigrants, but will confine the econometric analysis to emigrants, due to lack of relevant information regarding the immigrants.

\footnotetext{
${ }^{3}$ See discussion of this point in Section 5 below.
} 
Note that our data include all potential emigrants as we have the records of all the Israelis participating in the labor market who pay taxes. ${ }^{4}$

Table 1

Number of individuals according to direction of migration and gender

\begin{tabular}{|c|c|c|c|c|c|c|c|c|c|}
\hline \multirow[b]{2}{*}{ Year } & \multicolumn{3}{|c|}{ In } & \multicolumn{3}{|c|}{ Out } & \multicolumn{3}{|c|}{ Total Sample } \\
\hline & Males & Females & Total & Males & Females & Total & Males & Females & Total \\
\hline 2000 & 281 & 88 & 369 & 836 & 356 & 1,192 & 9,946 & 4,499 & 14,445 \\
\hline 2001 & 227 & 82 & 309 & 1,381 & 714 & 2,095 & 10,589 & 5,094 & 15,683 \\
\hline 2002 & 270 & 108 & 378 & 1,228 & 594 & 1,822 & 10,032 & 4,861 & 14,893 \\
\hline 2003 & 229 & 100 & 329 & 979 & 481 & 1,460 & 8,899 & 4,365 & 13,264 \\
\hline 2004 & 267 & 99 & 366 & 1,001 & 484 & 1,485 & 8,867 & 4,326 & 13,193 \\
\hline 2005 & 286 & 127 & 413 & 866 & 429 & 1,295 & 9,043 & 4,187 & 13,230 \\
\hline 2006 & 323 & 149 & 472 & 960 & 429 & 1,389 & 10,563 & 5,008 & 15,571 \\
\hline 2007 & 324 & 129 & 453 & 1,102 & 517 & 1,619 & 11,862 & 5,612 & 17,474 \\
\hline 2008 & 444 & 188 & 632 & 1,091 & 471 & 1,562 & 12,842 & 6,267 & 19,109 \\
\hline 2009 & 357 & 149 & 506 & 817 & 390 & 1,207 & 12,682 & 6,431 & 19,113 \\
\hline 2010 & 361 & 183 & 544 & 901 & 453 & 1,354 & 14,215 & 7,164 & 21,379 \\
\hline Total & 3,369 & 1,402 & 4,771 & 11,162 & 5,318 & 16,480 & 119,540 & 57,814 & 177,354 \\
\hline Average & 306 & 127 & 434 & 1,015 & 483 & 1,498 & 10,867 & 5,256 & 16,123 \\
\hline
\end{tabular}

SOURCE: Based on Central Bureau of Statistics Migration data.

4 As the source of our data is the Israeli Tax Authority, the only wage earners excluded from our database are those that do not report their income. They constitute a very small group in Israel, because employers are required to withhold taxes when paying their employees, making it virtually impossible for wage earners to avoid reporting their taxable income. 
Table 2

Emigrants and Israel 2010 by tax bracket (percent)

\begin{tabular}{lccccc}
\hline & \multicolumn{5}{c}{ Bracket } \\
\cline { 2 - 6 } Year & 3 & 4 & 5 & 6 & 7 \\
\hline 2000 & 55.6 & 30.2 & 12.6 & 1.1 & 0.4 \\
2001 & 55.6 & 29.7 & 13.5 & 0.9 & 0.4 \\
2002 & 57.0 & 29.0 & 12.6 & 1.1 & 0.3 \\
2003 & 58.9 & 27.8 & 12.0 & 1.0 & 0.4 \\
2004 & 58.7 & 27.8 & 12.1 & 1.0 & 0.3 \\
2005 & 58.5 & 27.1 & 12.4 & 1.4 & 0.6 \\
2006 & 57.0 & 27.3 & 13.5 & 1.7 & 0.5 \\
2007 & 55.8 & 27.1 & 14.6 & 2.0 & 0.5 \\
2008 & 54.3 & 26.3 & 16.2 & 2.6 & 0.7 \\
2009 & 53.2 & 27.7 & 15.5 & 2.7 & 0.8 \\
2010 & 52.7 & 27.7 & 16.0 & 2.8 & 0.7 \\
\hline Total & 56.0 & 28.0 & 13.8 & 1.7 & 0.5 \\
\hline Israel 2010 & 46.7 & 27.0 & 22.8 & 2.9 & 0.7 \\
\hline
\end{tabular}

SOURCE: Based on Central Bureau of Statistics Migration and Household income surveys data.

The total number of migrants reported in Table 1 (on the right-most column of the table) refers to individuals that migrated at least once during the sample period. Thus, for a given year, we report both the number of individuals that actually migrated during that year, and on the right-most column of the table, we report the number of people that worked during that year and migrated in any other year during our sample period. All observations include migrants whose income falls in the third income tax bracket or higher (in table 2 we report for each year the composition of migrants by income tax brackets). Note that examining the data in this particular manner allows us to consider the timing of migration. Given that the sample is composed of individuals with a high propensity to emigrate, the timing of emigration and whether it was affected by the tax reductions is our main interest.

Table 3 breaks the migrants population into age groups. Most of them are in the middle range: $25-34$ and 35-44 years old. In Table 4, we report the composition of migrants by religion. The Muslim population is under-represented in the list of migrants relative to its share of the general population. Individuals of "other religions" (individuals who are neither Jews, nor Christians or Muslims) are over-represented relative to their share in the general population. 


\section{Table 3}

Emigrants by age group (percent)

\begin{tabular}{lcccccc}
\hline Year & \multicolumn{7}{c}{ Age group } \\
\cline { 2 - 7 } & Up to 24 & $25-34$ & $35-44$ & $45-54$ & $55-64$ & 65 and above \\
\hline 2000 & 5.5 & 41.2 & 33.7 & 14.8 & 4.0 & 0.8 \\
2001 & 4.6 & 40.9 & 31.6 & 16.0 & 5.9 & 1.1 \\
2002 & 6.1 & 45.0 & 32.4 & 11.2 & 4.4 & 0.9 \\
2003 & 3.8 & 44.0 & 33.6 & 12.3 & 5.5 & 0.8 \\
2004 & 3.3 & 41.6 & 35.5 & 13.5 & 5.3 & 0.7 \\
2005 & 3.2 & 41.2 & 36.1 & 12.4 & 6.3 & 0.9 \\
2006 & 4.2 & 41.5 & 38.4 & 12.0 & 3.7 & 0.2 \\
2007 & 4.3 & 40.0 & 39.1 & 11.5 & 4.7 & 0.4 \\
2008 & 4.7 & 38.9 & 39.0 & 11.8 & 4.6 & 1.0 \\
2009 & 4.6 & 41.1 & 37.0 & 11.4 & 5.2 & 0.7 \\
2010 & 3.8 & 39.3 & 39.5 & 10.7 & 5.9 & 0.8 \\
\hline Total & 4.4 & 41.4 & 35.8 & 12.6 & 5.1 & 0.8 \\
Israel 2010 & 0.6 & 19.5 & 32.5 & 26.5 & 18.1 & 2.7 \\
\hline
\end{tabular}

SOURCE: Based on Central Bureau of Statistics Migration and Household income surveys data.

\section{Table 4}

Emigrants by religion (percent)

\begin{tabular}{lcc|ccc}
\hline Year & Jewish & Others & Muslim & Druze & Christian \\
\hline 2000 & 87.9 & 9.1 & 1.1 & 0.1 & 1.8 \\
2001 & 86.5 & 10.4 & 1.2 & 0.1 & 1.8 \\
2002 & 84.6 & 12.1 & 1.2 & 0.1 & 2.0 \\
2003 & 83.5 & 13.2 & 1.4 & 0.1 & 1.8 \\
2004 & 82.9 & 13.7 & 1.6 & 0.1 & 1.7 \\
2005 & 82.9 & 13.7 & 1.5 & 0.2 & 1.7 \\
2006 & 82.6 & 13.7 & 1.8 & 0.2 & 1.7 \\
2007 & 83.7 & 12.7 & 1.9 & 0.2 & 1.5 \\
2008 & 85.2 & 11.2 & 2.1 & 0.2 & 1.3 \\
2009 & 87.6 & 8.6 & 2.3 & 0.2 & 1.4 \\
2010 & 88.2 & 7.9 & 2.5 & 0.2 & 1.3 \\
\hline Total & 85.2 & 11.3 & 1.7 & 0.2 & 1.6 \\
Israel 2010 & & 94.6 & & 5.4 & \\
\hline
\end{tabular}

SOURCE: Based on Central Bureau of Statistics Migration and Household income surveys data.

In Table 5, we present the income characteristics of the sample, by reporting the annual mean and quartile wages of the migrants. We observe that wage rates are lower than the average in Israel in 2010. In order to learn about the relative position of migrants we compare in Table 6 their monthly wages to the corresponding monthly wages of all wage earners. It turns out that the distribution is similar to that in the general population in 2010. 


\section{Table 5}

Emigrants' and Israel 2010 annual wage, mean and quartiles (nominal NIS)

\begin{tabular}{lcccc}
\hline Year & Mean & $\mathrm{p} 25$ & $\mathrm{p} 50$ & $\mathrm{p} 75$ \\
\hline 2000 & 133,948 & 87,144 & 111,243 & 161,433 \\
2001 & 130,313 & 85,896 & 109,327 & 160,947 \\
2002 & 126,825 & 85,744 & 107,799 & 155,344 \\
2003 & 123,398 & 84,931 & 105,393 & 151,427 \\
2004 & 125,435 & 84,782 & 105,606 & 152,105 \\
2005 & 125,826 & 84,335 & 104,357 & 153,796 \\
2006 & 128,525 & 84,463 & 105,690 & 158,566 \\
2007 & 129,225 & 81,821 & 105,251 & 159,870 \\
2008 & 136,370 & 83,143 & 108,292 & 168,714 \\
2009 & 135,812 & 83,829 & 108,224 & 168,730 \\
2010 & 139,414 & 84,648 & 110,452 & 170,756 \\
\hline Total & 130,834 & 84,822 & 107,553 & 160,087 \\
Israel 2010 & 202,765 & 123,156 & 159,156 & 227,634 \\
\hline
\end{tabular}

SOURCE: Based on Central Bureau of Statistics Migration and Household income surveys data.

\section{Table 6}

Relative monthly wage of emigrants and Israel 2010 (from $3^{\text {rd }}$ bracket upwards) compared to average wage

\begin{tabular}{lcccccccccc}
\hline Percentiles & $1 \%$ & $5 \%$ & $10 \%$ & $25 \%$ & $50 \%$ & $75 \%$ & $90 \%$ & $95 \%$ & $99 \%$ & Mean \\
\hline Emigrants & 0.7 & 0.8 & 0.9 & 1.0 & 1.4 & 2.0 & 2.9 & 3.6 & 5.8 & 1.8 \\
Israel 2010 & 0.9 & 0.9 & 1.0 & 1.2 & 1.6 & 2.2 & 3.1 & 4.0 & 6.9 & 2.0 \\
\hline
\end{tabular}

SOURCE: Based on Central Bureau of Statistics Migration and Household income surveys data.

In Table 7, we look at the level of education of migrants and the composition of their occupations. We see that migrants have lower education levels compared to the general population, with the exception of high-tech industries at the range of 13-15 years of education.

\section{Table 7}

Migrants and Israel 2010 by Years of Schooling (percent)

\begin{tabular}{lccccc}
\hline & \multicolumn{5}{c}{ Migrants } \\
\cline { 2 - 5 } Years of schooling & In & Out & Hi tec & Low tec & Israel 2010 \\
\hline $0-10$ & 4.6 & 8.0 & 3.0 & 14.5 & 3.4 \\
$11-12$ & 27.4 & 31.5 & 26.0 & 42.4 & 20.8 \\
$13-15$ & 24.0 & 27.8 & 33.6 & 23.8 & 26.0 \\
$16+$ & 44.0 & 32.6 & 37.4 & 19.3 & 49.9 \\
\hline
\end{tabular}

SOURCE: Based on Central Bureau of Statistics Migration and Household income surveys data.

Table 8 shows that relative to the general population emigrants are more likely to be married. 


\section{Table 8}

Migrants and Israel 2010 population by marital status (percent)

\begin{tabular}{lccc}
\hline & In & Out & Israel 2010 \\
\hline Married & 84.4 & 82.7 & 81.5 \\
Non-Married & 15.6 & 17.3 & 18.5 \\
\hline
\end{tabular}

SOURCE: Based on Central Bureau of Statistics Migration and Household income surveys data.

In order to learn more about migrants' characteristics, we looked at their wages by the technological intensity of their occupation, as shown in Table $9 .{ }^{5}$ The average wage ratio of migrants is high for hi-tech industries. It is also higher than unity for low-tech industries. The hourly alternative wage in the US (which is a strong migration reference for Israelis) for hightech jobs is fairly high, reaching a level exceeding three times the average wage in Israel. This makes the emigration decision a relevant option. ${ }^{6}$

\section{Table 9}

Wage and alternative wage by technological intensity

\begin{tabular}{lcccccc}
\hline & \multicolumn{2}{c}{ In } & \multicolumn{2}{c}{ Out } & \multicolumn{2}{c}{ Israel } \\
\cline { 2 - 5 } & Hi tec & Low tec & Hi tec & Low tec & Total & 2010 \\
\hline monthly wage (NIS) & 19,516 & 10,678 & 17,061 & 10,278 & 14,030 & 16,676 \\
wage ratio (relative to gender & & & & & & \\
peers average wage) & 2.4 & 1.3 & 2.2 & 1.3 & 1.8 & 2.0 \\
average income tax rate & $20.5 \%$ & $9.9 \%$ & $20.0 \%$ & $11.0 \%$ & $15.0 \%$ & \\
net hourly alternative wage in US\$ & 34.8 & 31.6 & 35.1 & 31.0 & 17.7 & \\
\hline
\end{tabular}

SOURCE: Based on Central Bureau of Statistics Migration and Household income surveys data.

In our econometric analysis we are interested in controlling for all factors that affect migration that are not related to the income tax reductions of 2000-2010. One such factor relates to participation in a program known as "Returning Home" which was launched by the Ministry of Migration during the 2000s, mainly after 2008. The program offered eligible participants an exemption from Israeli tax of their foreign sourced income, for a period of ten years. Figure 3 below shows the number of migrants affected by the program over the sample period. As we focus in our regressions on emigrants, it is worth noting that, ex-ante, eligible workers are expected to be less likely to emigrate, as their tax shelter is dependent upon staying in Israel. We have controlled for these migrants in our regressions.

\footnotetext{
${ }^{5}$ The classification was used by the Central Bureau of Statistics and became the standard in Israel. High tech includes medicines, computers, electronic and optic devices, planes and spaceships; low tech includes food, drinks, tobacco, textile, shoes, leather, paper, printing, wood and furniture.

${ }^{6}$ In Section 5 below we elaborate on the methodology used to calculate the net hourly alternative wage rates.
} 
Figure 3

Number of workers who migrated in "Returning Home" Program

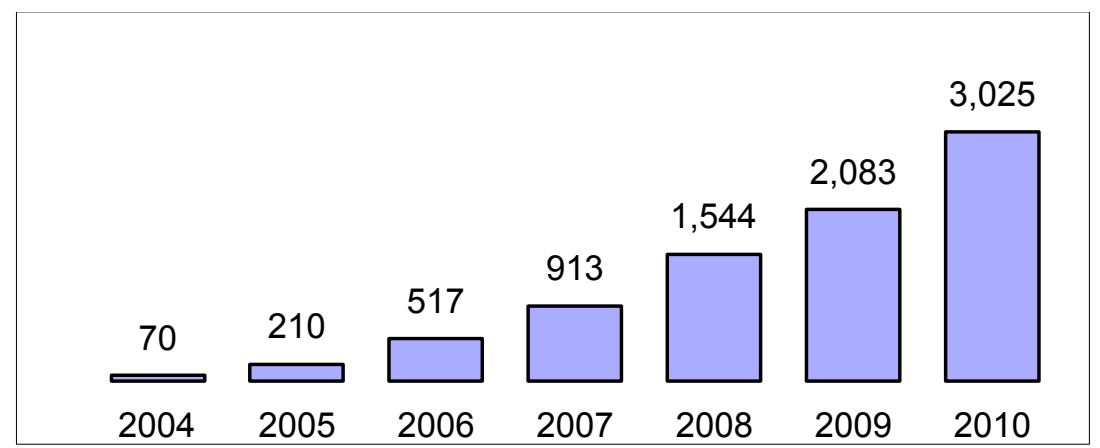

SOURCE: Based on Ministry of Aliyah and Immigrant Absorption and Central Bureau of Statistics Migration data.

In Table 10, we show the composition of emigrants by the number of months they worked during the year. This table clearly shows that most emigrants were full-time workers.

Table 10

Emigrants by work Months (frequency and percent)

\begin{tabular}{|c|c|c|c|c|c|c|c|c|c|c|c|c|c|c|}
\hline year & $\begin{array}{c}0 \\
\text { (Business only) }\end{array}$ & 1 & 2 & 3 & 4 & 5 & 6 & 7 & 8 & 9 & 10 & 11 & 12 & Total \\
\hline \multirow[t]{2}{*}{2000} & 351 & 165 & 207 & 202 & 217 & 240 & 313 & 349 & 392 & 363 & 453 & 474 & 8,562 & 12,288 \\
\hline & 2.9 & 1.3 & 1.7 & 1.6 & 1.8 & 2.0 & 2.6 & 2.8 & 3.2 & 3.0 & 3.7 & 3.9 & 69.7 & 100.0 \\
\hline \multirow[t]{2}{*}{2001} & 352 & 198 & 201 & 270 & 297 & 309 & 371 & 429 & 532 & 469 & 527 & 517 & 8,765 & 13,237 \\
\hline & 2.7 & 1.5 & 1.5 & 2.0 & 2.2 & 2.3 & 2.8 & 3.2 & 4.0 & 3.5 & 4.0 & 3.9 & 66.2 & 100.0 \\
\hline \multirow[t]{2}{*}{2002} & 346 & 228 & 212 & 260 & 281 & 275 & 358 & 395 & 477 & 421 & 450 & 458 & 8,181 & 12,342 \\
\hline & 2.8 & 1.9 & 1.7 & 2.1 & 2.3 & 2.2 & 2.9 & 3.2 & 3.9 & 3.4 & 3.7 & 3.7 & 66.3 & 100.0 \\
\hline \multirow[t]{2}{*}{2003} & 330 & 223 & 221 & 211 & 248 & 254 & 297 & 316 & 410 & 340 & 375 & 383 & 7,099 & 10,707 \\
\hline & 3.1 & 2.1 & 2.1 & 2.0 & 2.3 & 2.4 & 2.8 & 3.0 & 3.8 & 3.2 & 3.5 & 3.6 & 66.3 & 100.0 \\
\hline \multirow[t]{2}{*}{2004} & 311 & 199 & 184 & 222 & 263 & 245 & 275 & 287 & 407 & 331 & 384 & 338 & 6,885 & 10,331 \\
\hline & 3.0 & 1.9 & 1.8 & 2.2 & 2.6 & 2.4 & 2.7 & 2.8 & 3.9 & 3.2 & 3.7 & 3.3 & 66.6 & 100.0 \\
\hline \multirow[t]{2}{*}{2005} & 372 & 213 & 202 & 198 & 243 & 247 & 300 & 265 & 375 & 298 & 353 & 367 & 6,537 & 9,970 \\
\hline & 3.7 & 2.1 & 2.0 & 2.0 & 2.4 & 2.5 & 3.0 & 2.7 & 3.8 & 3.0 & 3.5 & 3.7 & 65.6 & 100.0 \\
\hline \multirow[t]{2}{*}{2006} & 431 & 238 & 185 & 202 & 279 & 293 & 317 & 339 & 424 & 334 & 384 & 422 & 7,409 & 11,257 \\
\hline & 3.8 & 2.1 & 1.6 & 1.8 & 2.5 & 2.6 & 2.8 & 3.0 & 3.8 & 3.0 & 3.4 & 3.8 & 65.8 & 100.0 \\
\hline \multirow[t]{2}{*}{2007} & 506 & 311 & 246 & 275 & 324 & 339 & 330 & 349 & 441 & 379 & 373 & 441 & 7,884 & 12,198 \\
\hline & 4.2 & 2.6 & 2.0 & 2.3 & 2.7 & 2.8 & 2.7 & 2.9 & 3.6 & 3.1 & 3.1 & 3.6 & 64.6 & 100.0 \\
\hline \multirow[t]{2}{*}{2008} & 558 & 304 & 248 & 259 & 368 & 331 & 345 & 384 & 452 & 438 & 419 & 557 & 8,259 & 12,922 \\
\hline & 4.3 & 2.4 & 1.9 & 2.0 & 2.9 & 2.6 & 2.7 & 3.0 & 3.5 & 3.4 & 3.2 & 4.3 & 63.9 & 100.0 \\
\hline \multirow[t]{2}{*}{2009} & 634 & 242 & 255 & 253 & 330 & 305 & 318 & 351 & 403 & 345 & 382 & 406 & 8,191 & 12,415 \\
\hline & 5.1 & 2.0 & 2.1 & 2.0 & 2.7 & 2.5 & 2.6 & 2.8 & 3.3 & 2.8 & 3.1 & 3.3 & 66.0 & 100.0 \\
\hline \multirow[t]{2}{*}{2010} & 727 & 207 & 206 & 272 & 321 & 319 & 360 & 369 & 436 & 378 & 435 & 470 & 8,986 & 13,486 \\
\hline & 5.4 & 1.5 & 1.5 & 2.0 & 2.4 & 2.4 & 2.7 & 2.7 & 3.2 & 2.8 & 3.2 & 3.5 & 66.6 & 100.0 \\
\hline \multirow[t]{2}{*}{ Total } & 4,918 & 2,528 & 2,367 & 2,624 & 3,171 & 3,157 & 3,584 & 3,833 & 4,749 & 4,096 & 4,535 & 4,833 & 86,758 & 131,153 \\
\hline & 3.8 & 1.9 & 1.8 & 2.0 & 2.4 & 2.4 & 2.7 & 2.9 & 3.6 & 3.1 & 3.5 & 3.7 & 66.2 & 100.0 \\
\hline
\end{tabular}

SOURCE: Based on Central Bureau of Statistics Migration data.

Emigration propensities are likely to be affected by the technological intensity of the worker's occupation (high- versus low-tech) as well as by the type of the employing entity 
(multinationals versus local firms). We conjecture that workers in the high-tech sector and in multinationals, ceteris paribus, have enhanced relocation opportunities and are, hence, more likely to emigrate. Table 11 provides some related summary statistics.

\section{Table 11}

Number of Emigrants by technological intensity and multinational company

\begin{tabular}{lccc}
\hline Year & Hi tech & Low tech & Multinational \\
\hline 2000 & 84 & 36 & 117 \\
2001 & 128 & 62 & 214 \\
2002 & 115 & 58 & 157 \\
2003 & 88 & 61 & 117 \\
2004 & 107 & 71 & 144 \\
2005 & 82 & 47 & 122 \\
2006 & 121 & 74 & 135 \\
2007 & 147 & 84 & 207 \\
2008 & 76 & 71 & 136 \\
2009 & 51 & 54 & 109 \\
2010 & 73 & 51 & 109 \\
\hline Total & 1,072 & 669 & 1,567 \\
Average & 97 & 61 & 142 \\
\hline
\end{tabular}

SOURCE: Based on Central Bureau of Statistics Migration and Household income surveys data.

\section{The Model}

In this section we propose a simple model that characterizes individuals' response to a persistent tax reduction announced by the government. The purpose of the model is to provide a parsimonious conceptual framework that highlights the dynamic migration incentives associated with tax reductions, from which we derive the key testable implication for our empirical analysis.

Consider a population of homogenous workers with inelastic labor supply whose per-period (net-of-tax) labor income is given by $1>0$ and whose utility from income is given by $U(I)$, where $U$ is strictly increasing. We simplify by assuming no discounting. Each worker considers the possibility of migration to a destination country for $S$ periods of time. For simplicity, we assume that after $S$ periods the worker returns to his home country and remains there permanently and further assume that workers cannot migrate for shorter time horizons. To capture the potential variation across individuals in job opportunities 
abroad and migration costs, we assume that, at each period, the reservation utility associated with migration for $S$ periods, denoted by $R$, is drawn from a continuous probability distribution function, $G$, with strictly positive densities, $G^{\prime}>0$, over some support $[\underline{R}, \bar{R}]$.

In the benchmark setting the probability of migration at each period is therefore given by:

(1) $\quad \operatorname{Pr}[R \geq S U(I)]=1-G[S U(I)]$

Now suppose that at period $t=0$ the government announces a tax reform, according to which each worker will be thereafter eligible for a tax reduction of $T>0$ per period, namely, his post-reform net income (per period) will be given by $1+T$.

We plausibly allow for time inconsistency, by considering the possibility that the government will ex-post renege on its announced policy reform. We assume that the government's propensity to renege on pre-announced policy reforms is unobserved by the workers. However, the realization (or lack of realization) of the tax reform suggested may serve as an informative signal for workers with respect to the propensity of the government to renege and thereby affect the probability of migration.

We assume that there are two types of government, denoted by $i=\mathrm{H}, \mathrm{L}$, differing in their propensity to renege on their announced policy reforms. Type-H implements its announced policy reform at any period $t>0$ with probability $0<q^{H}<1$, whereas, Type-L implements its announced policy reform at any period $t>0$ with probability $0<q^{L}<1$, with $q^{H}>q^{L}$. That is, Type-H is more committed to its policy announcement and less likely to renege than Type-L. Notice that for tractability we simplify by assuming that the probability to implement the policy reform is identical and independent across time for each type of government. Finally, we assume that the prior probabilities assigned by the workers to Type-H and Type-L governments are given respectively, by $0<\alpha<1$ and $0<1-\alpha<1$. 
Let $E\left[V_{t} \mid Z_{t}\right]$ denote the expected utility (evaluated at the beginning of period $t$ for $t>1$ ) associated with not migrating, namely, remaining in the home country for $S$ periods of time starting at period $t$, conditional on the history $Z_{t}$, where $Z_{t} \equiv\left\{k_{1}, k_{2}, \ldots, k_{t-1}\right\}$ with $k_{s}$ denoting an indicator function assuming the value of one if the policy reform is implemented at period $s$ and zero otherwise. We further denote by $E\left[V_{1}\right]$ the (unconditional) expected utility evaluated at the beginning of period $t=1$.

The probability of migration at each period $t$, conditional on the history $Z_{t}$, is hence given by:

(2) $\quad \operatorname{Pr}\left[R \geq E\left[V_{t} \mid Z_{t}\right]\right]=1-G\left[E\left[V_{t} \mid Z_{t}\right]\right]$.

Thus, the larger the expected utility associated with non-migration is the lower the probability of migration turns out to be.

We let $P_{t}\left[k=H \mid Z_{t}\right]$ and $P_{t}\left[k=L \mid Z_{t}\right]$ denote the posterior probabilities (evaluated at the beginning of period $t$, for $t>1$ ) assigned by the workers to Type-H and Type-L governments, respectively, conditional on the history $Z_{t}$. By virtue of our previous assumptions the prior probabilities assigned to Type- $\mathrm{H}$ and Type-L, respectively, are given by $P_{1}[k=H]=\alpha$ and $P_{1}[k=L]=1-\alpha$.

Employing the above notation one can derive expressions for the expected utility from nonmigration. The unconditional expected utility at the outset (upon announcement of the tax reform) is given by:

(3) $\quad E\left[V_{1}\right]=S\left(\left[\alpha q^{H}+(1-\alpha) q^{L}\right] U(I+T)+\left[\alpha\left(1-q^{H}\right)+(1-\alpha)\left(1-q^{L}\right)\right] U(I)\right)$

The expected utility at the beginning of period $t, t>1$, depends on the history, $Z_{t}$, and given by: 
(4) $\quad E\left[V_{t} \mid Z_{t}\right]=S\left\{\begin{array}{c}{\left[P_{t}\left[k=H \mid Z_{t}\right] q^{H}+P_{t}\left[k=L \mid Z_{t}\right] q^{L}\right] U(I+T)+} \\ {\left[P_{t}\left[k=H \mid Z_{t}\right]\left(1-q^{H}\right)+P_{t}\left[k=L \mid Z_{t}\right]\left(1-q^{L}\right)\right] U(I)}\end{array}\right\}$

By virtue of the independence property, the posterior probabilities and hence the expected utility at any period $t$ are invariant to any permutation of the history vector $Z_{t}$. That is, the order of realizations has no impact on the expected utility. Employing the invariance property one can show that the posterior probability assigned to Type- $\mathrm{H}$ at (the beginning of) any period $t$ is increasing with respect to the number of periods (prior to $t$ ) in which the tax reduction has been implemented and decreasing with respect to the number of periods in which the government reneged on its announced policy reform.

To see this let $F_{t}^{m}$ denote the set of all histories, $Z_{t}$, during which the tax reduction has been implemented in exactly $m$ periods. Further let an element in the set $F_{t}^{m}$ be denoted by $Z_{t}^{m}$. Notice that by the invariance property the posterior probability at $t$ associated with any history $Z_{t}^{m}$ is identical. We need to show that for any $t, P_{t}\left[k=H \mid Z_{t}^{m}\right]>P_{t}\left[k=H \mid Z_{t}^{n}\right]$ for $m>n$. We will prove the property for $m=n+1$. The result will then follow by induction.

By virtue of Bayes' Rule it follows that:

$$
P_{t}\left[k=H \mid Z_{t}^{n+1}\right]=\frac{P_{t-1}\left[k=H \mid Z_{t-1}^{n}\right] q^{H}}{P_{t-1}\left[k=H \mid Z_{t-1}^{n}\right] q^{H}+P_{t-1}\left[k=L \mid Z_{t-1}^{n}\right] q^{L}}>P_{t-1}\left[k=H \mid Z_{t-1}^{n}\right],
$$

where the inequality sign follows as $q^{H}>q^{L}$.

Applying again Bayes' Rule it follows that:

$$
P_{t}\left[k=H \mid Z_{t}^{n}\right]=\frac{P_{t-1}\left[k=H \mid Z_{t-1}^{n}\right]\left(1-q^{H}\right)}{P_{t-1}\left[k=H \mid Z_{t-1}^{n}\right]\left(1-q^{H}\right)+P_{t-1}\left[k=L \mid Z_{t-1}^{n}\right]\left(1-q^{L}\right)}<P_{t-1}\left[k=H \mid Z_{t-1}^{n}\right],
$$

where the inequality sign follows as $q^{H}>q^{L}$.

Combining (5) and (6) then yields:

$$
P_{t}\left[k=H \mid Z_{t}^{n+1}\right]>P_{t}\left[k=H \mid Z_{t}^{n}\right] .
$$


This completes the proof.

Employing (4), following some algebraic manipulations and re-arranging yields:

$$
\begin{aligned}
& E\left[V_{t} \mid Z_{t}^{n+1}\right]-E\left[V_{t} \mid Z_{t}^{n}\right]= \\
& S\left(q^{H}-q^{L}\right)[U(I+T)-U(I)]\left\{P_{t}\left[k=H \mid Z_{t}^{n+1}\right]-P_{t}\left[k=H \mid Z_{t}^{n}\right]\right\}>0,
\end{aligned}
$$

where the inequality sign follows from (7) and as $q^{H}>q^{L}$.

We conclude that as the government persists in implementing its pre-announced tax reduction, the posterior probability assigned to Type- $\mathrm{H}$ increases and hence, the gains from non-migration increase, reflecting an updated lower assessment of the probability of reneging by the government. This implies, by virtue of (2), a corresponding decrease in the probability of migration. The latter constitutes the key testable implication for our empirical analysis below, namely the negative relation between the accumulated tax reductions and the propensity to emigrate.

\section{The Effect of Permanent Tax Reductions: Econometric Analysis}

In this section we perform an econometric analysis of the emigration decision, using a framework that embeds the key insight from the model presented above, namely that the emigration decision is associated with the cumulative gains from tax reductions, reflecting a persistent implementation of a pre-announced tax reform. ${ }^{7}$

As explained in Section 3, the data is based on migration flows that are longer than one year. This opens the possibility that an emigrant left Israel for a short period of time, say, 2 years, and then returned to Israel. Two comments are in order: i) our econometric analysis is not aimed at explaining permanent migration, but rather attempts to shed light on the relationship between the timing of migration (for shorter or longer periods of time) and the generosity of the tax reductions; ii) concerning emigrants, we have the possibility of tracking

\footnotetext{
${ }^{7}$ In the appendix we provide a supplementary difference-in-difference analysis testing the illustrative model's predictions.
} 
their employment history, assuming that once they come back they return to the labor market - which is the representative case (note that according to the data shown above, the bulk of emigrants take their decision at an early stage - between 25 and 44 years old). There are 9,428 observations of this type, which represent 5.3 percent of our migrations sample. For 2,000 out of them we have data on the duration of their stay abroad, which averages 521 days, with a minimum of 364 days and a maximum of 3,097 days.

\subsection{Emigration sensitivity to Tax Reductions for high-tech and low-tech workers}

In order to allow the data to provide disaggregate information, we will separate our analysis by looking into two groups of individuals: high-tech and low-tech workers. High-tech industries are based on the global development of technologies around the world, and consequently the human capital (know-how associated with education and/or on-the-job experience) of workers in these industries is typically transferrable to a large extent across countries and job prospects of these workers are, hence, less sensitive to fluctuations in local demand. In contrast, low-tech workers are more dependent on local demand, thus we expect that the net benefits from migration would be higher for high-tech workers. ${ }^{8}$ The difference in the education patterns between these two sectors is readily reflected in Table 7: the share of workers in the high-tech with years of schooling weakly exceeding 16 is 37 percent, compared with 19 percent in the low tech.

We generalize this framework by including all other relevant factors that affect emigration, which include: gender, age, religion, participation in the "Returning Home" Program, marital status, affiliation with multinational companies, and key economic factors. The latter include the main macroeconomic and microeconomic variables. Among the first category, we included the unemployment rate in Israel and in the main destination countries (G7). Concerning microeconomic factors, we calculated the alternative wage based on Mincer regressions, namely the hypothetical wage rate that could be earned in the destination country conditional on the observed characteristics of the worker. The calculation is based on the findings shown by Polachek [(1981) and more recently (2008)) who constructed Mincer equations that include occupational affiliation, age and gender as explanatory variables of the observed wage in a large group of developed economies. Using the reported

\footnotetext{
8 Jaimovich and Siu (2012) show, for instance, that the demand for jobs that are homogeneous and that do not require creativity (routine and middle-skilled jobs) collapses during recessions, resulting in persistent unemployment within these occupations.
} 
coefficients we imputed an alternative wage for each emigrant, which is based on his/her own personal characteristics (gender, age and occupation). For this purpose we used data from the US, France and the UK. Based on administrative data regarding the statutory tax rates in place, we have calculated the average tax rate for each individual and derived his/her alternative net wage.

We also included as explanatory variables key public goods provided by the government (i.e., represented by government expenditure) in Israel and abroad: education and health. It turned out that government expenditure on education for the different levels (primary, secondary and higher education) did not have a significant impact. Health expenditure, in contrast, resulted in significant coefficients. Our data source for the expenditure on both education and health is the OECD.

The key regression specification takes the following form:

$E_{i, t}=C_{i}+A N W_{i, t}+W_{i, t}+I T_{i, t}+Z_{t}$

where the dependent variable $\mathrm{E}$ represents the emigration decision for a worker of sector $\mathrm{i}$ at time $t$. Note that individuals may decide to emigrate in every single year during the sample, whereas in practice they do so at a particular timing. $C$ represents the emigration cost/benefit that is idiosyncratic to each sector, where $i=1$ for high tech and $i=2$ for low tech; ANW is the alternative net wage at the destination country which is calculated as a weighted average of the alternative wage rates in the US (50 percent), France ( 25 percent) and the UK (25 percent) $)^{9} ; \mathrm{W}$ is the gross wage in Israel; IT is the income tax; and $\mathrm{Z}$ is the vector of the control variables, including gender, age, squared age, religion (Muslim, Christian, Druze), unemployment in Israel, unemployment in $\mathrm{G} 7$ countries, marital status and some interaction terms as we explain later. Note also that we include the business wage (namely, the cost incurred by the employer) as an additional variable, although for data quality considerations we base our analysis on employees' wages.

In Table 12 we show the results of the basic specification using d(probit). Columns 1 and 2 present the fixed effect for high-tech and low-tech employees respectively, in a separate way (i.e., compared to all other sectors); Column 3 presents the results when fixed effects appear together at the same regression (compared to all other sectors besides those two). The coefficients represent the marginal effect of a change in the independent variables, in probability terms. Note that all (micro and macro) variables have the expected sign. The

\footnotetext{
${ }^{9}$ The US and Europe account for 90 percent of Israelis' emigrations.
} 
alternative net wage is positive which means that raising it implies an increase in emigration from Israel. The wage in Israel has a negative sign, whereas the income tax has a positive sign. The coefficient of taxation means that if we reduce taxes by 1,000 NIS, the probability of emigration decreases by 0.00032 . The "Returning Home" Program, as expected, has a negative and significant sign. A rise in unemployment in $G 7$ countries reduces emigration from Israel, whereas a rise in unemployment in Israel works in the opposite direction, as expected. Also health expenditure coefficients have the expected sign: increasing health expenditure abroad is positively correlated to emigration, while the opposite is true when health expenditure is increased in Israel.

Note further that females are less likely to emigrate, whereas young people are more likely to do so (and vice versa for old people). Note also that the non-Jewish population (Muslim, Druze and Christian) is less likely to emigrate (although for Christians the coefficient is not significantly different from zero).

The most interesting result from the point of view of our model is related to migration costs and tax reductions. Migration costs are captured by the constant term of each sector: hightech and low-tech. Note that for High-tech the constant is positive, which implies that in this sector there is a positive (ex-ante) propensity to emigrate, reflecting a net benefit derived from emigrating. High-tech workers can relocate incurring relatively low mobility costs and in many cases, migration can in fact enhance job prospects for the skilled migrants. For lowtech workers, in contrast, migration costs are sizable. Accordingly, the constant term is negative for the Low-tech workers.

As expected, tax reductions decrease the likelihood of emigration, although, notably, the coefficient is lower (in absolute terms) than that associated with the wage. Thus, in order to avoid a 'brain drain' the government has to more than compensate the potential emigrants for the gross wage differentials between the origin and destination countries, through the implemented tax cuts. Note that as we include the gross wage rate and the income tax as two separate explanatory variables in the regression, consistency considerations imply that the coefficients of W and IT should be equal in absolute value (and with opposite sign). The apparent inconsistency may reflect a 'risk-premium' that measures the uncertainty revolving around whether the government will actually implement the pre-announced tax reductions.

Hi-tech and Low-tech workers are obviously heterogeneous. Hence, in order to quantify the true impact of the tax reductions on these markedly different types of workers it is 
necessary to examine separately the effect of tax reductions on each group of workers. This is done in Table 13.

Table 12

Emigration Response to Tax Reductions and Migration Costs

\begin{tabular}{|c|c|c|c|c|c|c|}
\hline Equation Number & 1 & & 2 & & 3 & \\
\hline \multirow[t]{2}{*}{ Dependent variable } & \multicolumn{2}{|l|}{ Out } & \multicolumn{2}{|l|}{ Out } & \multicolumn{2}{|l|}{ Out } \\
\hline & $\mathrm{dF} / \mathrm{dx}$ & $\mathrm{Pv}$ & $\mathrm{dF} / \mathrm{dx}$ & $\mathrm{Pv}$ & $\mathrm{dF} / \mathrm{dx}$ & $\mathrm{Pv}$ \\
\hline US, UK and France net alternative wage ${ }^{a}$ & 0.00004 & $(0)^{\star \star *}$ & 0.00005 & $(0)^{\star \star \star}$ & 0.00005 & $(0)^{\star \star \star}$ \\
\hline Employee wage $^{\mathrm{a}}$ & -0.00074 & $(0)^{\star * *}$ & -0.00074 & $(0)^{\star * *}$ & -0.00074 & $(0)^{\star * \star}$ \\
\hline Business wage $^{a}$ & -0.00081 & $(0)^{\star * *}$ & -0.00082 & $(0)^{\star * *}$ & -0.00082 & $(0)^{\star \star *}$ \\
\hline Income tax ${ }^{a}$ & 0.00032 & $(0)^{* * *}$ & 0.00032 & $(0)^{\star * \star}$ & 0.00032 & $(0)^{* \star *}$ \\
\hline Female & -0.00489 & $(0.001)^{\star \star \star}$ & -0.00438 & $(0.003)^{* \star \star}$ & -0.00447 & $(0.002)^{\star \star \star}$ \\
\hline Age & 0.00351 & $(0)^{* \star *}$ & 0.00346 & $(0)^{\star \star \star}$ & 0.00346 & $(0)^{\star \star *}$ \\
\hline $\mathrm{Age}^{2}$ & -0.00003 & $(0)^{\star \star \star}$ & -0.00003 & $(0)^{\star \star \star}$ & -0.00003 & $(0)^{\star \star \star}$ \\
\hline Muslim & -0.02528 & $(0)^{\star \star *}$ & -0.02557 & $(0)^{\star \star \star}$ & -0.02552 & $(0)^{\star \star \star}$ \\
\hline Druze & -0.05265 & $(0)^{\star * *}$ & -0.05282 & $(0)^{\star \star \star}$ & -0.05278 & $(0)^{\star \star \star}$ \\
\hline Christian & -0.00357 & $(0.4)$ & -0.00376 & $(0.4)$ & -0.00373 & $(0.4)$ \\
\hline "Returning Home" Program & -0.07051 & $(0)^{* * *}$ & -0.07050 & $(0)^{* \star *}$ & -0.07049 & $(0)^{* \star *}$ \\
\hline Unemployment in Israel & 0.01552 & $(0.003)^{\star \star *}$ & 0.01516 & $(0.004)^{* \star *}$ & 0.01554 & $(0.003)^{\star * *}$ \\
\hline Unemployment in G7 & -0.02104 & $(0.001)^{\star \star \star}$ & -0.02156 & $(0)^{\star \star \star}$ & -0.02110 & $(0.001)^{\star \star \star}$ \\
\hline Single & 0.00934 & $(0)^{\star * *}$ & 0.00992 & $(0)^{\star \star \star}$ & 0.00981 & $(0)^{* \star *}$ \\
\hline Single Female & -0.01101 & $(0.001)^{\star \star \star}$ & -0.01134 & $(0)^{* \star *}$ & -0.01127 & $(0.001)^{\star \star \star}$ \\
\hline Multinational & 0.00517 & $(0.024)^{\star \star}$ & 0.00568 & $(0.013)^{* \star}$ & 0.00529 & $(0.021)^{\star *}$ \\
\hline Unemployment in Israel * High tech & -0.00894 & $(0)^{* * *}$ & -0.00408 & $(0.009)^{* \star *}$ & -0.00900 & $(0)^{* \star *}$ \\
\hline Unemployment in G7 * High tech & -0.00393 & -0.263 & 0.00821 & $(0)^{\star \star \star}$ & -0.00380 & $(0.3)$ \\
\hline Year 2000 & 0.19249 & $(0.003)^{\star * \star}$ & 0.18940 & $(0.003)^{\star \star \star}$ & 0.19611 & $(0.003)^{* \star *}$ \\
\hline Year 2001 & 0.15175 & $(0)^{\star \star *}$ & 0.15033 & $(0)^{\star * \star}$ & 0.15396 & $(0)^{* * *}$ \\
\hline Year 2009 & -0.02392 & $(0)^{\star \star *}$ & -0.02374 & $(0)^{\star * *}$ & -0.02413 & $(0)^{* * *}$ \\
\hline Year $2000 *$ High tech & -0.01893 & $(0.017)^{\star \star}$ & -0.00935 & $(0.25)$ & -0.01859 & $(0.020)^{\star *}$ \\
\hline Year 2001 * High tech & -0.02430 & $(0)^{\star \star *}$ & -0.01978 & $(0.004)^{\star \star \star}$ & -0.02400 & $(0)^{\star \star \star}$ \\
\hline Terror & 0.00019 & $(0)^{* \star *}$ & 0.00019 & $(0)^{* * *}$ & 0.00019 & $(0)^{* * *}$ \\
\hline Health_abroad & 0.00029 & $(0.001)^{\star \star *}$ & 0.00029 & $(0.001)^{\star \star \star}$ & 0.00029 & $(0.001)^{\star * *}$ \\
\hline Health * age $50+$ & 0.00001 & $(0)^{\star \star *}$ & 0.00001 & $(0)^{\star \star *}$ & 0.00001 & $(0)^{\star \star \star}$ \\
\hline Health_Israel & -0.00029 & $(0.004)^{\star \star \star}$ & -0.00029 & $(0.005)^{\star \star \star}$ & -0.00029 & $(0.004)^{\star \star \star *}$ \\
\hline High Tech & 0.17556 & $(0)^{* * *}$ & & & 0.17000 & $(0)^{\star \star \star}$ \\
\hline Low Tech & & & -0.01574 & $(0)^{\star \star \star}$ & -0.01554 & $(0)^{* \star *}$ \\
\hline Pseudo $\mathrm{R}^{2}$ & 0.088 & & 0.088 & & 0.089 & \\
\hline Number of observations & 177,354 & & 177,354 & & 177,354 & \\
\hline
\end{tabular}

Probit regression, reporting marginal effects. $* * *$ Significant at $1 \%$; $*$ Significant at $5 \%$.

SOURCE: Based on Central Bureau of Statistics Migration data.

${ }^{\mathrm{a}} 1,000$ NIS, current prices. 
Table 13

Emigration Response to Tax Reductions and Migration Costs allowing for interactions

\begin{tabular}{|c|c|c|c|c|c|c|}
\hline \multirow{3}{*}{$\begin{array}{l}\text { Equation Number } \\
\text { Dependent variable }\end{array}$} & \multicolumn{2}{|l|}{1} & \multicolumn{2}{|l|}{2} & \multicolumn{2}{|l|}{3} \\
\hline & Out & & Out & & Out & \\
\hline & $\mathrm{dF} / \mathrm{dx}$ & $\mathrm{PV}$ & $\mathrm{dF} / \mathrm{dx}$ & $\mathrm{PV}$ & $\mathrm{dF} / \mathrm{dx}$ & $\mathrm{Pv}$ \\
\hline US, UK and France net alternative wage ${ }^{a}$ & 0.00006 & $(0)^{\star \star \star}$ & 0.00005 & $(0)^{\star \star \star}$ & 0.00006 & $(0)^{\star \star \star}$ \\
\hline Employee wage $^{a}$ & -0.00087 & $(0)^{\star \star \star}$ & -0.00072 & $(0)^{\star \star \star}$ & -0.00084 & $(0)^{\star \star \star}$ \\
\hline Business wage $^{a}$ & -0.00093 & $(0)^{\star \star *}$ & -0.00080 & $(0)^{* \star *}$ & -0.00091 & $(0)^{\star \star *}$ \\
\hline Income tax ${ }^{a}$ & 0.00074 & $(0)^{\star \star \star}$ & 0.00030 & $(0)^{\star \star \star}$ & 0.00071 & $(0)^{\star \star *}$ \\
\hline Female & -0.00253 & $(0.089)^{*}$ & -0.00428 & $(0.004)^{\star \star *}$ & -0.00254 & $(0.087)^{*}$ \\
\hline Age & 0.00333 & $(0)^{\star \star \star}$ & 0.00330 & $(0)^{\star \star \star}$ & 0.00329 & $(0)^{* * *}$ \\
\hline $\mathrm{Age}^{2}$ & -0.00002 & $(0)^{\star \star \star}$ & -0.00002 & $(0)^{\star \star \star}$ & -0.00002 & $(0)^{\star \star \star}$ \\
\hline Muslim & -0.02498 & $(0)^{\star \star \star}$ & -0.02569 & $(0)^{\star \star \star}$ & -0.02515 & $(0)^{* \star *}$ \\
\hline Druze & -0.05221 & $(0)^{\star \star \star}$ & -0.05256 & $(0)^{\star \star \star}$ & -0.05210 & $(0)^{* \star \star}$ \\
\hline Christian & -0.00317 & $(0.5)$ & -0.00357 & $(0.4)$ & -0.00305 & $(0.5)$ \\
\hline "Returning Home" Program & -0.07023 & $(0)^{\star \star \star}$ & -0.07036 & $(0)^{\star \star \star}$ & -0.07012 & $(0)^{\star \star \star}$ \\
\hline Unemployment in Israel & 0.01587 & $(0.002)^{\star \star \star}$ & 0.01545 & $(0.003)^{\star \star *}$ & 0.01572 & $(0.003)^{* * *}$ \\
\hline Unemployment in G7 & -0.02157 & $(0)^{\star \star *}$ & -0.02096 & $(0.001)^{\star \star \star}$ & -0.02133 & $(0.001)^{\star * *}$ \\
\hline Single & 0.00948 & $(0)^{\star \star \star}$ & 0.00951 & $(0)^{\star \star \star}$ & 0.00924 & $(0)^{\star \star \star}$ \\
\hline Single Female & -0.01208 & $(0)^{\star \star \star}$ & -0.01105 & $(0.001)^{\star \star \star}$ & -0.01174 & $(0)^{* \star *}$ \\
\hline Multinational & 0.00488 & $(0.034)^{\star *}$ & 0.00556 & $(0)^{\star \star \star}$ & 0.00479 & $(0.037)^{\star *}$ \\
\hline High Tech & 0.14914 & $(0)^{* \star *}$ & 0.18888 & $(0.015)^{\star \star}$ & 0.15489 & $(0)^{* * *}$ \\
\hline Low Tech & -0.01493 & $(0)^{\star \star *}$ & 0.12212 & $(0)^{\star \star \star}$ & 0.10957 & $(0)^{\star \star \star}$ \\
\hline Unemployment in Israel * High tech & -0.00643 & $(0.001)^{\star * \star}$ & -0.00450 & $(0)^{\star \star \star}$ & -0.00655 & $(0)^{\star \star \star}$ \\
\hline Unemployment in G7 * High tech & -0.00665 & $(0.065)^{\star}$ & -0.00844 & $(0.2)$ & -0.00662 & $(0.060)^{*}$ \\
\hline High tech up to age 35 & -0.01581 & $(0.001)^{\star \star \star}$ & -0.01491 & $(0.001)^{\star \star \star}$ & -0.01590 & $(0.001)^{\star \star \star}$ \\
\hline Year 2000 & 0.20848 & $(0.002)^{\star \star \star}$ & 0.20112 & $(0.002)^{\star * *}$ & 0.21070 & $(0)^{\star \star \star}$ \\
\hline Year 2001 & 0.16062 & $(0)^{\star * *}$ & 0.15727 & $(0)^{\star * *}$ & 0.16240 & $(0.002)^{\star * *}$ \\
\hline Year 2009 & -0.02477 & $(0)^{\star \star \star}$ & -0.02441 & $(0)^{\star \star \star}$ & -0.02491 & $(0)^{\star \star \star}$ \\
\hline Year 2000 * High tech & -0.01355 & $(0.1)$ & -0.01730 & $(0.031)^{\star \star}$ & -0.01358 & $(0.099)^{*}$ \\
\hline Year 2001 * High tech & -0.02157 & $(0.002)^{\star \star \star}$ & -0.02335 & $(0.001)^{\star \star \star}$ & -0.02162 & $(0.002)^{\star \star *}$ \\
\hline Terror & 0.00019 & $(0)^{\star \star \star}$ & 0.00019 & $(0)^{\star \star \star}$ & 0.00020 & $(0)^{\star \star \star}$ \\
\hline Health_abroad & 0.00031 & $(0.001)^{\star \star \star}$ & 0.00030 & $(0.001)^{\star \star \star}$ & 0.00031 & $(0.001)^{\star \star \star}$ \\
\hline Health * age $50+$ & 0.00001 & $(0)^{\star \star *}$ & 0.00001 & $(0)^{* * *}$ & 0.00001 & $(0)^{* * *}$ \\
\hline Health_Israel & -0.00031 & $(0.003)^{\star \star \star}$ & -0.00031 & $(0.003)^{\star \star \star}$ & -0.00031 & $(0.002)^{\star * *}$ \\
\hline High tech * Employee wage ${ }^{a}$ & 0.00026 & $(0)^{\star \star \star}$ & & & 0.00023 & $(0)^{\star \star \star}$ \\
\hline High tech * Business wage ${ }^{a}$ & -0.00071 & $(0.36)$ & & & -0.00073 & $(0.35)$ \\
\hline High tech * Income tax ${ }^{a}$ & -0.00070 & $(0)^{* * *}$ & & & -0.00067 & $(0)^{* \star *}$ \\
\hline Low tech * Employee wage ${ }^{a}$ & & & -0.00138 & $(0)^{\star \star \star}$ & -0.00128 & $(0)^{* \star *}$ \\
\hline Low tech ${ }^{*}$ Business wage ${ }^{a}$ & & & -0.00115 & $(0)^{* \star *}$ & -0.00096 & $(0)^{* * *}$ \\
\hline Low tech * Income tax ${ }^{a}$ & & & 0.00221 & $(0)^{\star \star \star}$ & 0.00199 & $(0)^{* * *}$ \\
\hline Pseudo $\mathrm{R}^{2}$ & 0.093 & & 0.090 & & 0.094 & \\
\hline Number of observations & 177,354 & & 177,354 & & 177,354 & \\
\hline
\end{tabular}

Probit regression, reporting marginal effects. ${ }^{* *}$ Significant at $1 \%$; $*$ Significant at $5 \%{ }^{*}$ Significant at $10 \%$

SOURCE: Based on Central Bureau of Statistics Migration data.

${ }^{\mathrm{a}} 1,000$ NIS, current prices. 
The results shown in Table 13 indicate that the signs of all coefficients are as expected, with a statistical significance that in most cases is less than 1 percent. Among the controls we included interactions of unemployment in Israel and in G7 countries, which show that hitech is less sensitive to local unemployment and more sensitive to unemployment abroad. We also controlled for years that represented a remarkable phase of a cycle: 2000 (high rate of growth) and 2001, 2002 and 2009 (recessions). For 2000 and 2001 we allowed for an interaction with high-tech, since 2000 represents the high-tech bubble and 2001 its burst. Interestingly these variables were all significant and with expected signs. Thus, in 2001, the sum of the coefficients associated with the year dummy and the interacted year dummy with the high-tech sector is slightly positive.

To understand the impact of the tax reduction on each group of workers it is necessary to compare the sum of coefficients that include also the interaction terms. From this point of view the results are suggestive. The interaction term of income tax for high-tech is negative, which implies that for this kind of workers the impact of tax reductions is less important when compared to the general case. The opposite is true for low-tech workers, for whom the interaction term is positive - which means that tax reductions are more effective for incentivizing low-tech workers to avoid emigration. These results are valid also for wages: the overall sensitivity of high-tech workers to wages declines when we allow for interactions, while the one of low-tech workers is enhanced.

In Table 14 we summarize the effect of these variables on emigration. An interesting issue is related to the calculation of the amount of the tax reduction for the purpose of simulating the effect of a hypothetical tax reduction on the number of emigrants. Note that since tax reductions analyzed in our paper are permanent, they can be implemented in a limited way: this is so because in the short run tax reductions lower tax revenues and consequently raise government deficit and debt, which means that their scope is limited. In the long-run, given that in Israel there is a budget deficit reduction law that prevents an increase in the deficit, a permanent tax reduction reduces the size of the government. Thus, permanent tax reductions that are implemented with a parallel reduction in government expenditure change the political economy equilibrium. In the case of Israel, there was a well-known general public protest that induced policy-makers to raise back the income and corporate tax rates after 2011, bringing them to the levels that prevailed in April 2007. ${ }^{10}$ For the

\footnotetext{
${ }^{10}$ See Achdut, Spivak and Strawczynski (2013).
} 
purposes of our simulation we only consider the tax reductions implemented until 2007, reflecting a feasible permanent tax reduction. ${ }^{11}$

The results indicate that the effect of tax reductions is much stronger for low-tech workers than for high-tech ones, implying that tax reductions are more effective for low-tech workers, who appear to be fairly sensitive to their pecuniary reward. In order to perform the simulation we stress first that the average wage of high-tech workers is 1.7 times higher than the one for low-tech. Thus, we reduce taxes by 1,000 NIS for low-tech workers and by 1,700 NIS for high-tech workers (ensuring that the reduction in percentage terms is identical across the two sectors). Reducing taxes by an annual amount of 1,000 NIS would reduce the number of low-tech emigrants by 81 , which represents approximately 133 percent of the annual emigration flow; whereas, for the high-tech sector, a tax reduction of 1,700 NIS would imply reducing emigration by 4 employees, which is only 5 percent of the annual emigration flow. These numbers reflect migration elasticities (with respect to the net-of-tax wage rates) of 0.25 and 0.05 for the low-tech and the high-tech workers, respectively, and an elasticity of 0.09 for all potential emigrants.

Note that these figures are substantially lower than the elasticity found by Kleven, Landais, Saez and Schultz (2014) for the Danish case. The latter may be attributed to the fact that the elasticity found by Kleven et al. (2014) reflects a short-term response to a temporary tax reform confined to the top bracket, whereas in our case, the elasticity reflects a long-term response to a permanent tax reduction associated with middle and high brackets. In addition, our analysis focuses on the reduction in emigration rates, and does not account for the corresponding likely increase in migration rates.

\footnotetext{
${ }^{11}$ Our calculation assumes that statutory tax rates remain at this level. The amount of the reduction was calibrated according to a monthly wage of 10,000 NIS, which is similar to the wage of low-tech workers who emigrated (see Table 9). According to recently published calculations by the Bank of Israel, further tax increases are needed in order to finance current government obligations.
} 
Table 14

The impact of Tax Reductions on Emigration

\begin{tabular}{lccc}
\hline & High tech & Low tech & Total \\
\cline { 2 - 4 } Leaving workers per year & 97 & 61 & 1,498 \\
Relevant population in 2010 & 59,584 & 29,909 & 919,121 \\
Tax effect (per 1,000 NIS) & & 0.003 & 0.0007 \\
$\begin{array}{l}\text { The number of employees who would not emigrate } \\
\text { for a reduction of 1,000 NIS of annual tax paid }\end{array}$ & & 81 & 651 \\
\hline $\begin{array}{l}\text { Tax effect (per 1,700 NIS) } \\
\text { The number of employees who would not emigrate } \\
\text { for a reduction of 1,700 NIS of annual tax paid }\end{array}$ & 4 & \\
\hline
\end{tabular}

SOURCE: Based on Central Bureau of Statistics Migration and Household income surveys data.

\subsection{The sensitivity of young and married employees to permanent tax reductions}

Another way to test our hypothesis is to check whether there is a difference between the impact of the tax-reduction on young employees and that on their older counterparts. Our conjecture is that permanent tax reductions are likely to affect most significantly the behavior of economic agents that are subject to a longer and sustainable benefit (young workers), and to a lesser extent the behavior of those who gain from tax reduction over a shorter time horizon (old workers approaching their retirement). In Table 15 we add interaction terms for young employees (up to 35 years old) and for old employees ( $55+$ years old, who are close to retirement). The regression included the same variables as in Table 12 (without the interactions for high-tech and low-tech), which are not shown for space considerations (significance and expected signs of the coefficients remained unchanged).

In line with our predictions, for younger employees, the interaction term has a positive coefficient in all regression specifications; whereas, the interaction term for older employees is not significant for women, and negative (with a low coefficient) for men. Further reinforcement of our predictions is obtained when we allow for an interaction with spouses (column 3). For young married couples (where both spouses are up to 35 years old) the coefficient of the interaction term is much larger (and still highly significant). It is important 
to stress that the Israeli income tax is applied on an individual basis, implying that both spouses benefit from the tax reductions. For individuals up to 35 that are married the migration elasticity is 0.18 , substantially higher than the elasticity calculated for the emigrants' population as a whole (0.09). The lesson for policy-makers is that permanent tax reductions in a system that is based on a personal basis are likely to reduce emigration of young and married couples.

\section{Table 15 - Do tax reductions affect more young employees?}

\begin{tabular}{|c|c|c|c|c|c|c|}
\hline Equation Number & 1 & & 2 & & 3 & \\
\hline \multirow[t]{2}{*}{ Dependent variable } & Out & & Out & & Out & \\
\hline & $\mathrm{dF} / \mathrm{dx}$ & $\mathrm{Pv}$ & $\mathrm{dF} / \mathrm{dx}$ & $\mathrm{Pv}$ & $\mathrm{dF} / \mathrm{dx}$ & $\mathrm{Pv}$ \\
\hline Employee wage $^{a}$ & -0.00084 & $(0)^{* * *}$ & -0.00084 & $(0)^{\star \star \star}$ & -0.00085 & $(0)^{\star \star \star}$ \\
\hline Business wage $^{a}$ & -0.00091 & $(0)^{* * *}$ & -0.00091 & $(0)^{\star \star \star}$ & -0.00091 & $(0)^{\star \star *}$ \\
\hline Income tax ${ }^{a}$ & 0.00068 & $(0)^{* * *}$ & 0.00068 & $(0)^{\star \star \star *}$ & 0.00069 & $(0)^{\star * *}$ \\
\hline Up to age 35 & -0.02496 & $(0)^{* * *}$ & -0.02491 & $(0)^{\star \star \star}$ & -0.02559 & $(0)^{\star \star *}$ \\
\hline Age $55^{+}$ & 0.00905 & $(0.019)^{\star \star}$ & & & & \\
\hline Male age $55^{+}$ & & & 0.01219 & $(0.01)^{\star *}$ & 0.01233 & $(0.009)^{* * *}$ \\
\hline Female age $50+$ & & & -0.00585 & $(0.23)$ & -0.00525 & $(0.29)$ \\
\hline Income tax ${ }^{a} *$ Up to age 35 & 0.00014 & $(0)^{* * *}$ & 0.00014 & $(0)^{\star \star \star}$ & 0.00008 & $(0.004)^{* * *}$ \\
\hline Income tax ${ }^{\mathrm{a} *}$ Age $55+$ & -0.00002 & $(0.64)$ & & & & \\
\hline Income tax ${ }^{\mathrm{a}}{ }^{*}$ Male age $55+$ & & & -0.00007 & $(0.056)^{*}$ & -0.00008 & $(0.05)^{*}$ \\
\hline Income tax ${ }^{a} *$ Female age $50+$ & & & 0.00010 & $(0.35)$ & 0.00010 & $(0.35)$ \\
\hline Income tax ${ }^{a} *$ Married up to age 35 & & & & & 0.00054 & $(0)^{\star \star \star}$ \\
\hline Pseudo $\mathrm{R}^{2}$ & 0.095 & & 0.095 & & 0.095 & \\
\hline Number of observations & 177,354 & & 177,354 & & 177,354 & \\
\hline
\end{tabular}

\section{Conclusion}

In this paper we build an analytical framework for analyzing the effect of permanent income tax reductions on emigration and conduct an empirical analysis of their impact, based on the Israeli tax reductions during 2004-2010. Our findings show that permanent tax reductions do have an effect on emigration. After carefully controlling for an extended set of covariates, including the predicted alternative net wage rates that emigrants could earn in the 
destination countries, we found that the tax reduction implemented in Israel reduced the emigration flows, primarily amongst the low-tech wage earners, who presumably assign a higher weight to pecuniary aspects (due to diminishing marginal utility from Income), relative to unobservable variables associated with the development of their career paths (such as networking), as well as, among young and married employees who are subject to a substantially larger tax reduction, as they face a longer working horizon compared to employees that are approaching retirement. 


\section{References}

Achdut, L., A. Spivak and M. Strawczynski (2013), "The development of taxes in Israel", The New Government Budget (Hebrew), fourth Budget Conference of the Economics and Society Program at Van leer, Policy Paper No 13, page 18.

Akcigit, Baslandze and Stantcheva (2015), "Taxation and the international mobility of inventors", NBER, WP 21024.

Bakija, J. M., and J. B. Slemrod. (2004) "Do the Rich Flee from High State Taxes? Evidence from Federal Estate Tax Returns," NBER Working Paper No. 10645.

Blumkin, T., E. Sadka and Y. Shem-Tov (2015). “International Tax Competition: Zero Tax Rate at the Top Re-established", International Tax and Public Finance, 22 (5), 760-776.

Blundell, R. and T. MaCurdy (1999). "Labor Supply: A Review of Alternative Approaches," in O. Ashenfelter and D. Card (eds.), Handbook of Labor Economics, Volume 3A, North-Holland, Amsterdam.

Borjas, G. J. (1999). "The Economic Analysis of Immigration." In: Orley C. Ashenfelter and David Card, Ed(s), Handbook of Labor Economics, Elsevier: Amsterdam, Volume 3A.

Borjas, G., I. Kauppinen and P. Poutvaara (2015), "Self-selection of emigrants: theory and evidence on stochastic dominance in observable and unobservable characteristics", NBER Working Paper No 21649, October.

Devereux, Michael P., and Rachel Griffith (2002), "Evaluating Tax Policy for Location Decisions." International Tax and Public Finance 10: 107-126.

Feldstein, M. and M. V. Wrobel (1998), "Can State Taxes Redistribute Income?" Journal of Public Economics 68, 369-396.

Ferejohn, J. (1986), “Incumbent Performance and Electoral Control”, Public Choice, 50, 5-25.

Gruber, J. and E. Saez (2002), "The elasticity of taxable income: evidence and implications", Journal of Public Economics 84, 1-32.

Gordon, R. H. and J. R. Hines (2002). "International taxation," in A. Auerbach and M.

Feldstein (eds.), Handbook of Public Economics, Volume 4, North-Holland, Amsterdam.

Griffith, Rachel, James Hines, and Peter B. Sørensen (2010). “International Capital 
Taxation." In Dimension of Tax Design: The Mirrlees Review, Oxford: Oxford University Press.

Jaimovich, N. and Siu, H.E. (2012), "The trend is the cycle: job polarization and jobless recoveries", NBER Working Paper 18334

Kirchgassner, Gebhard, and Werner Pommerehne. 1996. "Tax Harmonization and Tax Competition in the European Union: Lessons from Switzerland." Journal of Public Economics 60: 351-371.

Kleven, Henrik J., Camille Landais, and Emmanuel Saez (2013). "Taxation and International Migration of Superstars: Evidence from the European Football Market" American Economic Review, 103 (5), 1892-1924.

Kleven, Henrik J., Camille Landais, Emmanuel Saez, and Esben A. Schultz (2014), "Taxation and International Migration of Top Earners: Evidence from the Foreigner Tax Scheme in Denmark." The Quarterly Journal of Economics, 129 (1), 333-378.

Lehmann, E., Simula, L. and Trannoy, A. (2014) "Tax Me If You Can: Optimal Non-linear Income Tax between competing Governments", Quarterly Journal of Economics, 129 (4), 1995-2030.

Liebig, T., P. A. Puhani, and A. Sousa-Poza (2007). “Taxation and Internal Migration: Evidence from the Swiss Census using Community-Level Variation in Income Tax Rates," Journal of Regional Science 47(4), 807-836.

Polachek, W. (1981), "Occupational Self-Selection: A Human Capital Approach to Sex Differences in Occupational Structure", The Review of Economics and Statistics, Vol. 63, No. 1: 60-69.

Polachek (2008), "Earnings Over the Lifecycle: The Mincer Earnings Function and Its Applications", Foundations and trends in Microeconomics, Now Publishers, Vol. 4 (3), 165272 .

Saez, Emmanuel, Joel Slemrod, and Seth Giertz (2012). "The Elasticity of Taxable Income with Respect to Marginal Tax Rates: A Critical Review." Journal of Economic Literature 50: 350.

Young, Cristobal, and Charles Varner (2011). "Millionaire Migration and State Taxation of Top Incomes: Evidence from a Natural Experiment." National Tax Journal 64: 255-284. 


\section{Appendix - Difference in Difference Estimation}

In this Appendix, we estimate the expected response to the tax reductions by performing a diff-in-diff exercise. Note that as shown in Figure 2, the tax reduction associated with the 3rd bracket is significantly lower than those associated with the higher brackets. Our analysis will focus on comparing the emigration flows before and after the tax reductions (i.e., before and after 2004) for the treated group ( $4^{\text {th }}$ and $5^{\text {th }}$ brackets) compared with the control group ( $3^{\text {rd }}$ bracket), in order to separate the change in emigration flows associated with the tax reductions from those attributed to the time trend. The latter is captured by the evolution of emigration flows within the $3^{\text {rd }}$ bracket, based on the identifying assumption that timetrends in emigration patterns are shared by individuals across income tax brackets. We have excluded from the analysis the $6^{\text {th }}$ and $7^{\text {th }}$ brackets due to a small number of observations.

In Figure A.1 we show the raw data, which confirms that the emigration reduction is substantial for the $4^{\text {th }}$ and $5^{\text {th }}$ brackets, and less so for the $3^{\text {rd }}$ bracket. Figure A. 2 calculates the averages for the periods before and after the tax reduction (2000-2003 compared to 2004-2010) which reveal a reduction of about 0.6 in average for the $4^{\text {th }}$ and $5^{\text {th }}$ brackets, compared to about 0.2 for the $3^{\text {rd }}$ bracket.

These figures call for performing a more careful difference in difference analysis, aimed at examining whether the reduction of emigration before and after the tax reductions was statistically different for the treated group (brackets $4^{\text {th }}$ and $5^{\text {th }}$ ) in comparison to the control group ( $3^{\text {rd }}$ bracket). In order to perform a careful diff-in-diff analysis, we used a propensity score matching (PSM) strategy for comparing individuals of the different brackets with general characteristics that are as similar as possible according to their PSM score. For this purpose we performed regressions that included the following characteristics: age, squared age, technology branch, major branch during the career, affiliation with a multinational company and residence in Dan Region (Tel Aviv and suburbs). 
Figure A.1 - Emigration flows as a share of the average flow for the different brackets

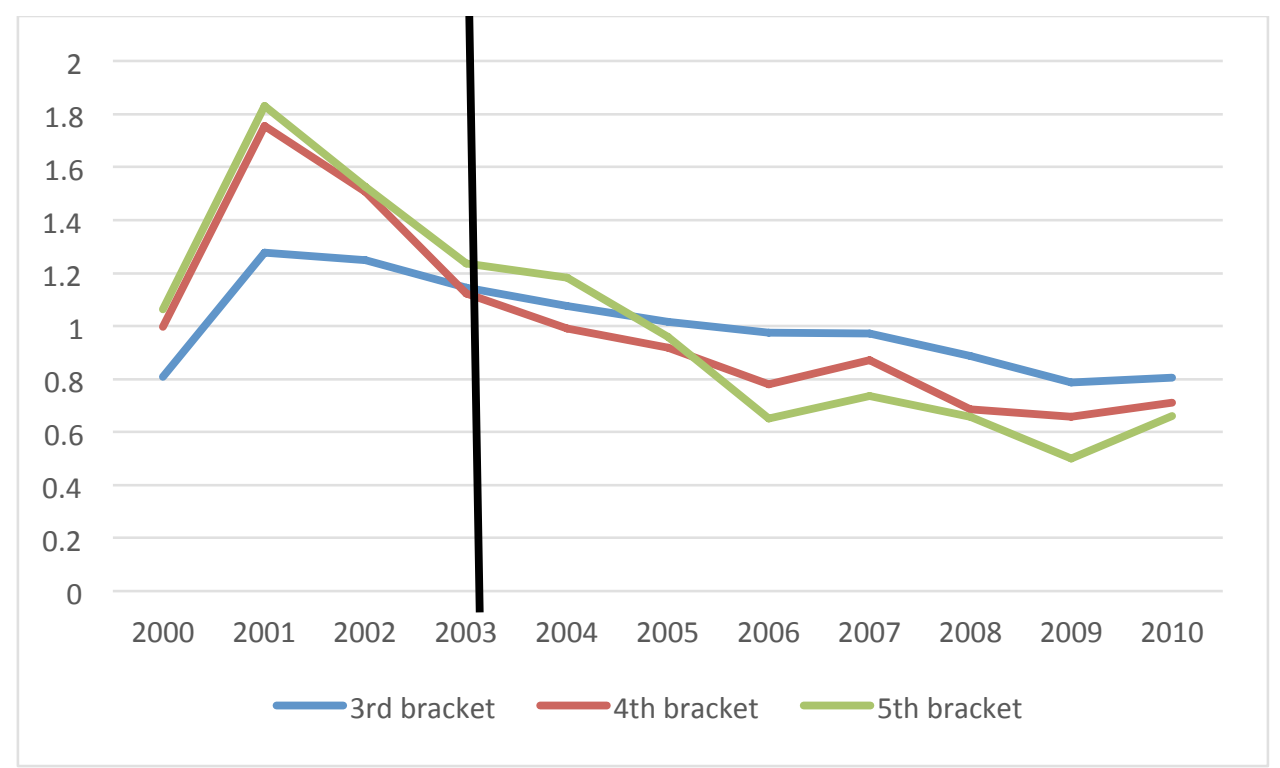

Figure A.2 - Average emigration flows in 2000-2003 and 2004-2010 as a share of the average flow for the different brackets

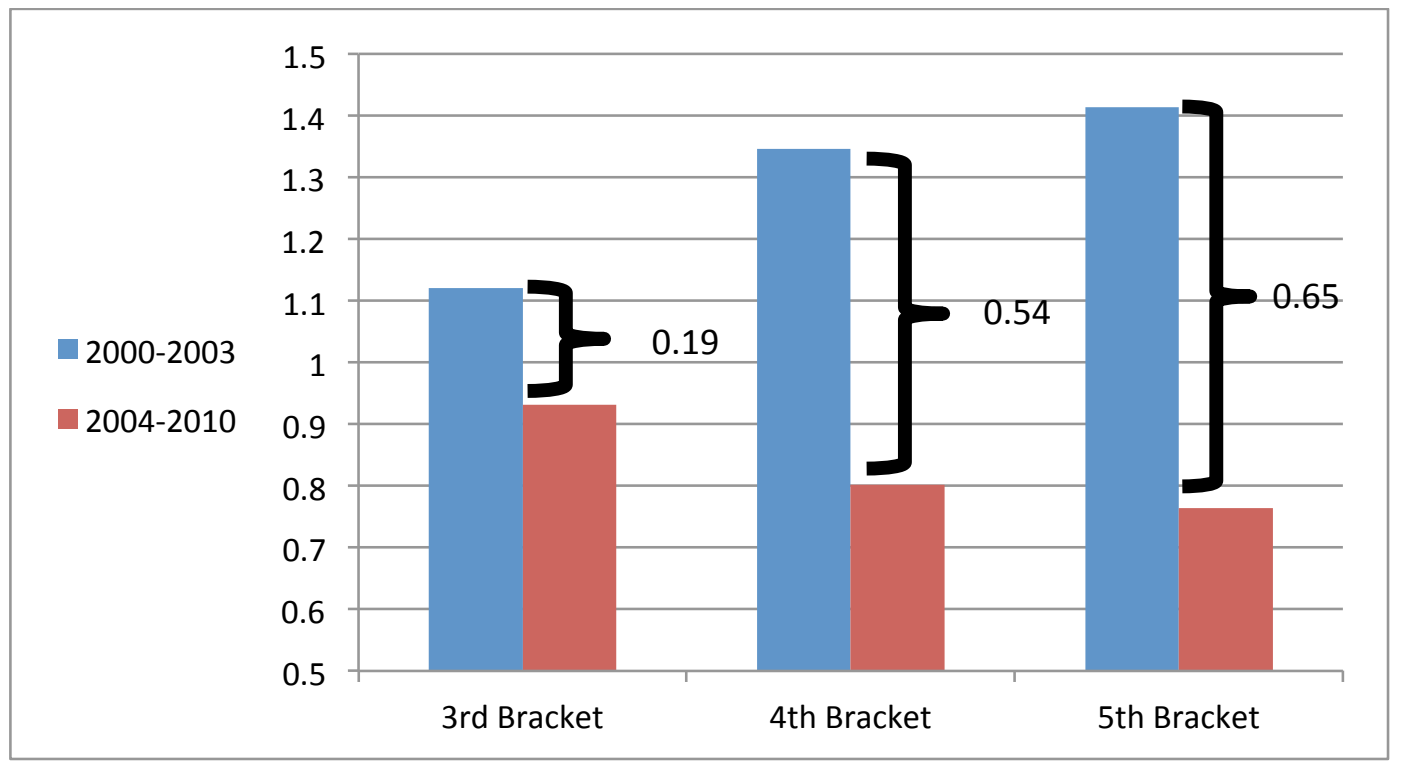

Tables A.1 and A.2 show the means of the different variables for unmatched and matched samples. Note that in both the $4^{\text {th }}$ and $5^{\text {th }}$ bracket the sample generated after using the PSM becomes very similar to the $3^{\text {rd }}$ bracket, allowing for a cleaner diff-in-diff exercise. 
Table A.1 - Means of matched variables: 4th bracket as treated group

\begin{tabular}{lcccc}
\hline \multirow{2}{*}{ Variable/Bracket } & \multicolumn{2}{c}{ Unmatched } & \multicolumn{2}{c}{ Matched } \\
\cline { 2 - 5 } & Treated & Control & Treated & Control \\
\hline Age & 36.24 & 37.25 & 36.24 & 36.29 \\
Squared age & 1402.2 & 1474.4 & 1402.2 & 1403.4 \\
Technology branch & 0.0766 & 0.118 & 0.0766 & 0.0756 \\
Major branch during the career & 58.028 & 61.92 & 58.028 & 57.96 \\
Multinational Company & 0.065 & 0.139 & 0.065 & 0.064 \\
Dan Region & 0.224 & 0.228 & 0.224 & 0.221 \\
\hline
\end{tabular}

Table A.2 - Means of matched variables: 5 th bracket as treated group

\begin{tabular}{lcccc}
\hline \multirow{2}{*}{ Variable/Bracket } & \multicolumn{2}{c}{ Unmatched } & \multicolumn{2}{c}{ Matched } \\
\cline { 2 - 5 } & Treated & Control & Treated & Control \\
\hline Age & 36.24 & 40.58 & 36.24 & 37.09 \\
Squared age & 1402.2 & 1746.3 & 1402.2 & 1472.2 \\
Technology branch & 0.0766 & 0.166 & 0.0766 & 0.0799 \\
Major branch during the career & 58.028 & 64.26 & 58.028 & 56.36 \\
Multinational Company & 0.065 & 0.17 & 0.065 & 0.062 \\
Dan Region & 0.224 & 0.205 & 0.224 & 0.211 \\
\hline
\end{tabular}

We now use the propensity scores matched individuals to test the diff-in-diff of emigration between the treated and control group, before and after the tax reduction. Figure A.3 shows the difference between the reduction in emigration flows associated with the $4^{\text {th }}$ and $5^{\text {th }}$ bracket and that associated with the $3^{\text {rd }}$ bracket, which was, roughly speaking, not subject to a tax reduction. The difference in the number of emigrants is reported as a share of the average flow of emigrants during the period that preceded the tax reduction (2000-2003). For example, in 2004 we see that the emigration reduction for the $4^{\text {th }}$ bracket was 25 percent (in terms of the previous emigration flow) higher - compared to the period before the tax reduction - than the one that occurred in the same year for the $3^{\text {rd }}$ bracket. Several observations emerge from closely examining figure A.3. First, the earliest jump in the reduction in emigration flows occurs within the $5^{\text {th }}$ bracket. Second, in line with our illustrative model, the reduction in the flow of emigrants increases over time within both the $4^{\text {th }}$ and $5^{\text {th }}$ brackets. This result is consistent with the feature shown in the model: actual tax 
reductions increase individuals' beliefs regarding the implementation of further (preannounced) tax reductions. Finally, the strongest effect is documented within the $5^{\text {th }}$ bracket, which was subject to a more intense tax reduction.

\section{Figure A.3}

The reduction in emigration by Income tax brackets (compared to the 3rd bracket, in \% of average number of emigrants by bracket during 2000-2003)

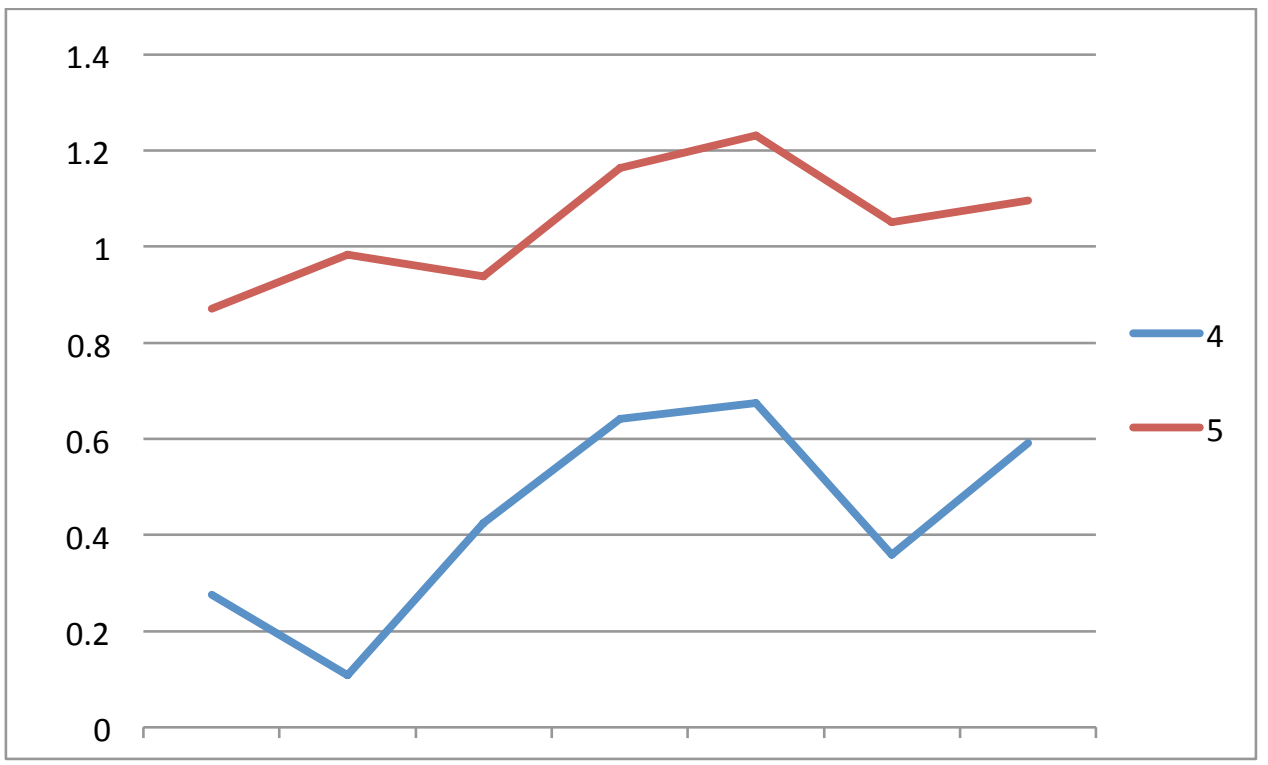

Table A.3 shows the statistical significance of the decrease in emigration in response to a persistent tax reduction during a sub-period (2004 until 2007) and for the whole period (2004 until 2010). Consistently with the findings shown above, the reported significance is based on the series following the PSM re-writing. To learn about the statistical significance we use $t$ values ${ }^{12}$.

\footnotetext{
${ }^{12}$ An Individual is assigned to brackets according to his permanent position; when it is volatile, his average bracket is used.
} 
Table A.3

The statistical significance of the diff-in-diff response to tax reductions ( $t$ values)

( ${ }^{*}$ significant at 10 percent; ${ }^{* *}$ significant at 5 percent; ${ }^{* * *}$ significant at 1 percent)

\begin{tabular}{|c|c|c|c|c|}
\hline \multirow{2}{*}{$\begin{array}{l}\text { Period/ } \\
\text { Bracket }\end{array}$} & \multicolumn{2}{|c|}{4} & \multicolumn{2}{|c|}{5} \\
\hline & $\begin{array}{l}\text { Using } 4^{\text {th }} \\
\text { bracket sd }\end{array}$ & $\begin{array}{l}\text { Using } 3^{\text {rd }} \\
\text { bracket sd }\end{array}$ & $\begin{array}{l}\text { Using } 5^{\text {th }} \\
\text { bracket sd }\end{array}$ & $\begin{array}{l}\text { Using } 3^{\text {rd }} \\
\text { bracket sd }\end{array}$ \\
\hline $\begin{array}{l}\text { 2004- } \\
2007\end{array}$ & $\begin{array}{l}-2.2 \\
(* *)\end{array}$ & $\begin{array}{l}-2.1 \\
(* *)\end{array}$ & -0.93 & $\begin{array}{c}-1.90 \\
\left({ }^{*}\right)\end{array}$ \\
\hline $\begin{array}{l}2004- \\
2010\end{array}$ & $\begin{array}{c}-1.75 \\
\left({ }^{*}\right)\end{array}$ & $\begin{array}{l}-1.9 \\
\left.{ }^{*}\right)\end{array}$ & $\begin{array}{c}-1.66 \\
\left(^{*}\right)\end{array}$ & $\begin{array}{c}-3.37 \\
\left({ }^{* * *}\right)\end{array}$ \\
\hline
\end{tabular}

During the 2004-2010 period, results are significant for the $4^{\text {th }}$ and the $5^{\text {th }}$ brackets, both when we use the own bracket standard deviation for calculating the t-statistic and when using the $3^{\text {rd }}$ bracket standard deviation, instead. These results emphasize that the reduction in emigration for employees belonging to the brackets that were subject to a permanent tax reduction was statistically significant. 